\title{
Sludge pretreatment by sonication: Effect of temperature
}

- Le Ngoc Tuan

University of Science, VNU-HCM

(Received on April $14^{\text {th }} 2015$, accepted on October $20^{\text {th }} 2015$ )

\section{ABSTRACT}

Effects of temperature $(T)$ rise in conditions of isothermal, adiabatic sonication -US (the same power input -Pus), and sole thermal hydrolysis, then its effects associated with Pus for the same specific energy input (ES) and the same treatment duration were investigated. The main results were that the evolution of sludge $T$ depended on Pus. In cases of the same ES (different $P$ us then different US duration), for the small probe, high $P_{\text {us }}$ were still beneficial for sludge disintegration. However, for the big probe, a low disintegration efficiency was Keywords: Adiabatic sonication, Sludge disintegration, Temperature effect, Waste activated sludge, Ultrasonic pretreatment.

\section{INTRODUCTION}

The wastewater treatment via the activated sludge process produces a large amount of biomass, of which improper disposal generates a significant threat to ecosystems. Thus anaerobic digestion $(A D)$ has been widely applied as a feasible method for the sludge treatment. However, the low rate of microbial conversion of hydrolysis stage requires a pretreatment of sludge. Ultrasonic irradiation (US) is proved as a feasible and promising mechanical disruption technique for the sludge pretreatment according to the treatment time and power, equating to specific energy input (ES): efficient sludge disintegration, improvement in biodegradability and bio-solid quality, increase in biogas/methane achieved at high $P_{\text {us }}$ due to the high sludge $T$ which leads to a significant damp of cavitation intensity. In cases of the same ES and treatment time, the sludge disintegration still benefited from high $P_{u s}$ if enough time was let for subsequent thermal hydrolysis. Therefore, the combined effect should be taken into account in optimization of US process: cavitation acts mainly during the early stage of the adiabatic US, then US being progressively damped by the increasing $T$, thermal hydrolysis takes over, being "boosted" by the initial work of US. production, no need for chemical additives, less [1].

Theory-based, increasing temperature $(T)$ will decrease the surface tension and raise the equilibrium vapour pressure of the medium, leading to easier bubble formation. However, these kinds of cavitation bubbles contain more vapors that reduce the $U S$ energy produced by the cavitation, thus reduce the amount of free radicals and also mechanical effects. Besides, simultaneously will provoke the attenuation or dampening effect on the propagation of $U S$ energy from the emitter through the system [2]. sludge retention time, and the sludge reduction great numbers of cavitation bubbles generating 
Nevertheless, in terms of sludge disintegration, the sludge ultrasonic pretreatment efficacy increases following an increase in the bulk $T$ as $T$ alone favors $C O D$ release. $U S$ treatment was proved to have two simultaneous effects: (i) vigorous agitation caused by the formation and explosion of tiny bubbles, and (ii) the increase in the bulk temperature. The higher the $T$ of solution, the more efficient the $U S$ disintegration was [3-6]. This is opposite to most power US applications as cavitation intensity is higher at low $T$.

This work aims at investigating effects of $T$ rise under "adiabatic" sonication then its effects associated with $P_{U S}$ (varying $P_{U S}$ and probe size) for the same $E S$ as well as the treatment duration. The best condition found in this work is expected to enhance the sludge disintegration, to save energy input, and to contribute to the the optimization of sludge US pretreatment.

\section{MATERIALS AND METHODS}

\section{Sludge samples}

Waste activated sludge (Table 1) was collected from Ginestous wastewater treatment plants (Toulouse, France) then sampled in $1 \mathrm{~L}$ plastic bottles and stored in a freezer [6]. The sludge was defrosted and diluted with distilled water before experiments to make synthetic sludge samples with $28 \mathrm{~g} / \mathrm{L}$ of TS [7].

Table 1. Characteristics of the sludge sample

\begin{tabular}{|c|c|c|c|c|}
\hline \multicolumn{2}{|l|}{ Parameter } & \multicolumn{3}{|c|}{ Value } \\
\hline & & $\overline{\mathbf{A}}$ & $\bar{B}$ & $\overline{\mathbf{C}}$ \\
\hline $\begin{array}{l}\text { Synthetic } \quad \text { sludge } \\
\text { samples }\end{array}$ & & Defrosted mixed sludge & $\begin{array}{l}\text { Defrosted secondary } \\
\text { sludge }\end{array}$ & $\begin{array}{l}\text { Defrosted secondary } \\
\text { sludge }\end{array}$ \\
\hline Total solids $(T S)$ & $\mathrm{g} / \mathrm{L}$ & 28.0 & 28.0 & 28.0 \\
\hline Mean $S C O D_{0}$ & $\mathrm{~g} / \mathrm{L}$ & 2.7 & 2.8 & 4.1 \\
\hline$S C O D_{\mathrm{NaOH}} 0.5 \mathrm{M}$ & $\mathrm{g} / \mathrm{L}$ & 18.5 & 22.7 & 22.1 \\
\hline Total COD (TCOD) & $\mathrm{g} / \mathrm{L}$ & 36.5 & 36.3 & 39.1 \\
\hline$S C O D_{\mathrm{NaOH}} / T C O D$ & $\%$ & 50.7 & 62.5 & 56.5 \\
\hline
\end{tabular}

\section{Ultrasound application}

Ultrasonic irradiation was emitted by a cuphorn ultrasound unit included in an autoclave reactor which was connected to a pressurized $N_{2}$ bottle (Fig. 1). The reactor, made of $316 \mathrm{~L}$ stainless steel, had an internal diameter of $9 \mathrm{~cm}$ and the depth of $18 \mathrm{~cm}$, for a usable capacity of 1 L. A cooling water stream was used to control $T$ of the solution at $28 \pm 2{ }^{\circ} \mathrm{C}$ during $U S$. The solution was stirred by a Rushton type turbine of $32 \mathrm{~mm}$ diameter at $500 \mathrm{rpm}$ [7]. $0.5 \mathrm{~L}$ of synthetic sludge sample was used for each experiment. The US equipment, supplied by Sinaptec, includes a $20 \mathrm{kHz}$ generator associated with probes of 13 and $35 \mathrm{~mm}$ diameter, labeled as $S P$ and $B P$, respectively. Maximum $P_{U S}$ (transferred from the generator to the transducer) is $100 \mathrm{~W}$ and $400 \mathrm{~W}$ for $S P$ and $B P$, respectively. Note that a power ratio of $360 / 50$ was applied between $B P$ and $S P$ as it corresponds to the surface ratio of the probes, allowing comparison at the same $I_{U S}$.

Different $U S$ durations (then $E S$ ) were tested: $E S=\left(P_{U S} * t\right) /(V * T S)$, where ES: specific energy input, energy per total solid weight $\left(\mathrm{kJ} / \mathrm{kg}_{\mathrm{TS}}\right), P_{U S}: U S$ power input $(\mathrm{W}), t: U S$ duration (s), $V$ : sludge volume (L), and TS: total solid concentration $(\mathrm{g} / \mathrm{L})$.

\section{Trang 24}


First, the effect of $T$ rise under "adiabatic" conditions was preliminarily investigated then its effect associated with $P_{U S}$ (varying $P_{U S}$ and probe size) for the same treatment duration. Experiments were duplicated and the coefficients of variation of $D D_{C O D}$ were about $5 \%$.

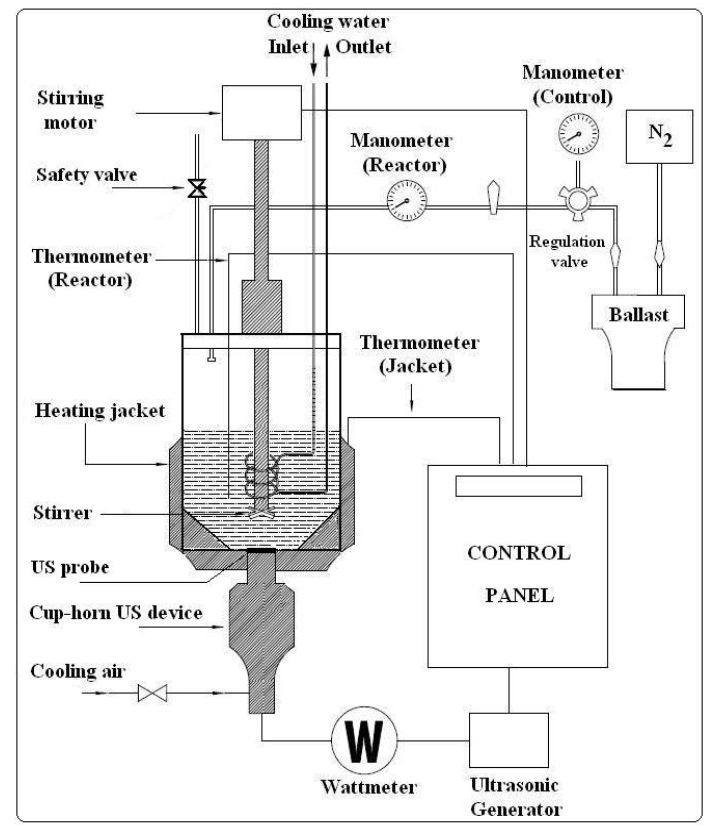

Fig. 1. Ultrasonic autoclave set-up

\section{Analytical methods}

Total and volatile solids (TS and VS, respectively) were measured according to standard methods. The degree of sludge disintegration $\left(D D_{C O D}\right)$ was calculated by determining the soluble $C O D$ after strong alkaline disintegration of sludge $\left(\mathrm{SCOD}_{\mathrm{NaOH}}\right)$ and the $C O D$ in the supernatant before and after the treatment (SCOD 0 and $S C O D$, respectively):

$$
\begin{gathered}
\mathrm{DD}_{\mathrm{COD}}=\left(\mathrm{SCOD}-\mathrm{SCOD}_{0}\right) /\left(\mathrm{SCOD}_{\mathrm{NaOH}}-\right. \\
\left.\mathrm{SCOD}_{0}\right) * 100(\%)
\end{gathered}
$$

To measure the $S C O D_{\mathrm{NaOH}}$ value, the sludge sample was mixed with $0.5 \mathrm{M} \mathrm{NaOH}$ at room $T$ for $24 \mathrm{~h}$ [5]. Besides, total COD (TCOD) was also measured by potassium dichromate oxidation method (standard AFNOR NFT 90101). Prior to SCOD determination, the supernatant liquid was filtered under vacuum using a cellulose nitrate membrane with $0.2 \mu \mathrm{m}$ pore size. The filtered liquid was subjected to $C O D$ analysis as per Hach spectrophotometric method. The change in the SCOD indirectly represents the quantity of organic carbon that has been transferred from the cell content (disruption) and solid materials (solubilisation) into the external liquid phase of sludge [9-10].

\section{RESULTS AND DISCUSSION}

\section{Effect of temperature rise under "adiabatic" conditions (without cooling)}

To evaluate the individual contribution of extreme macro and micro mixing caused by cavitation and increase in the bulk $T$, different operating procedures were carried out for mixed (Fig. 2A) and secondary sludge (Fig. 2B): (1) $U S$ under isothermal conditions (cooling at $28 \pm 2{ }^{\circ} \mathrm{C}$ ), (2) US under "adiabatic" conditions, (3) thermal hydrolysis: without $U S$ and with progressive increase of $T$ as recorded in (2), and (4) $5 \mathrm{~min}$ of $U S$ and progressive increase of $T$ afterwards (this series was conducted only on the secondary sludge). 


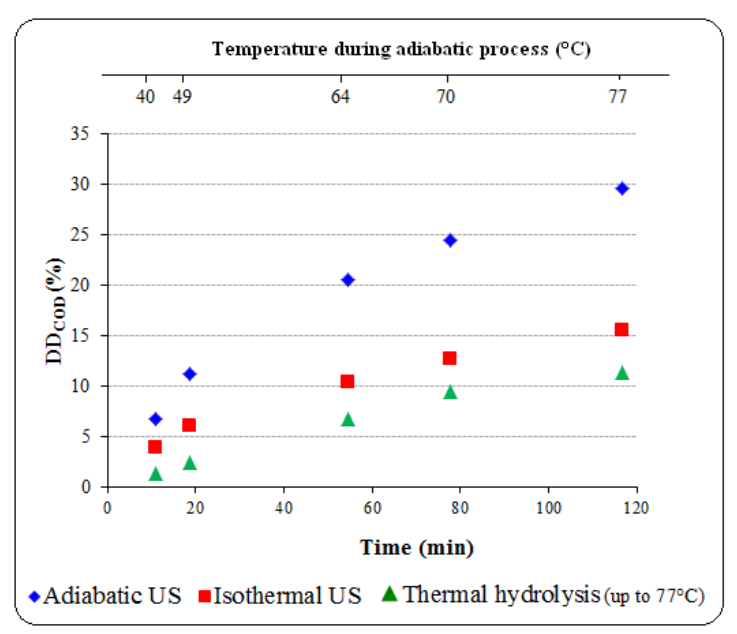

A

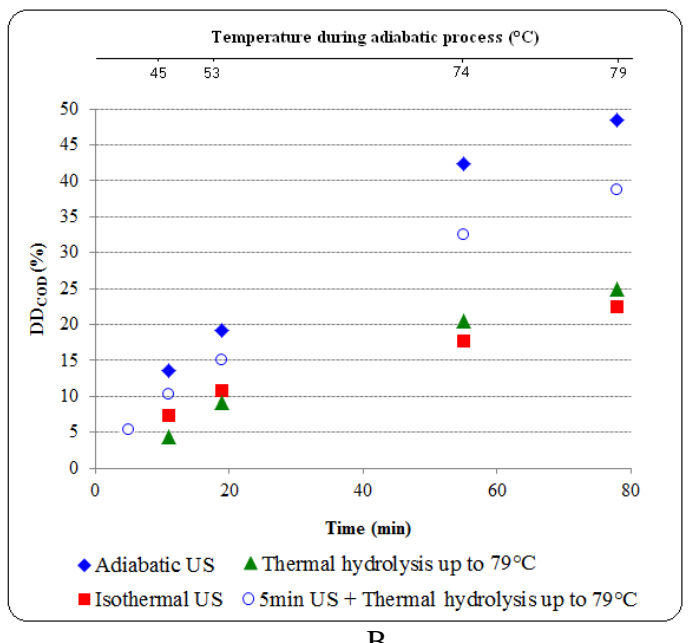

Fig 2. Effect of T profile* on time-evolution of sludge disintegration (DDcoD): $\mathrm{Pus}=150 \mathrm{~W}, \mathrm{BP}, \mathrm{Fs}_{\mathrm{S}}=20 \mathrm{kHz}, \mathrm{TS}=$ $28 \mathrm{~g} / \mathrm{L}$, and atmospheric pressure.

(A) Mixed sludge (Table 1A), (B) Secondary sludge (Table 1B)

*The upper $\mathrm{x}$-axis indicates the evol ution of $\mathrm{T}$ during adiabatic US and thermal hydrolysis (note that higher $\mathrm{T}$ at th same ES was achieved with the new equipment)

Fig. 2 shows that $D D_{C O D}$ values under the adiabatic $U S$ were the highest, followed by those under the short time $U S+$ thermal hydrolysis, then under the low $T$ sonication and the thermal hydrolysis only. $D D_{C O D}$ of sonicated samples under cooling $\left(28{ }^{\circ} \mathrm{C}\right)$ were about half of those obtained under the adiabatic US. It could be seen that (i) cavitation and thermal hydrolysis seem to show almost additional effects during the adiabatic US, (ii) thermal hydrolysis of early disrupted sludge is faster than that of raw sludge (Fig. 2B); therefore the combined effect is actually more complex: cavitation acts mainly during the early stage of the adiabatic $U S$, then the US being progressively damped by the increasing $T$, thermal hydrolysis takes over, being "boosted" by the initial work of $U S$. The resulting positive effect of combining $U S$ and $T$ for the sludge disintegration is in agreement with $\mathrm{Chu}$ et al. [8], Kidak et al. [6] and Li et al. [10] but opposite to most power US applications in which $T$ only damps cavitation.

\section{Effect of $T$ associated with $P_{U S}$ for the same treatment duration}

First, the effect of $T$ associated with $P_{U S}$ (varying $P_{U S}$ and probe size) on $D D_{C O D}$ was investigated at the same $E S: 50-100 \mathrm{~W}$ for $S P$ and 50-360 W for $B P$. Results are given in Figs. 3 and 4 . As expected, the evolution of the sludge $T$ was found to depend on the $P_{U S}$ : the higher $P_{U S}$ resulted in a more rapid increase of $T$ and yielded a higher final value at given $E S$ as the reactor was not fully insulated. 


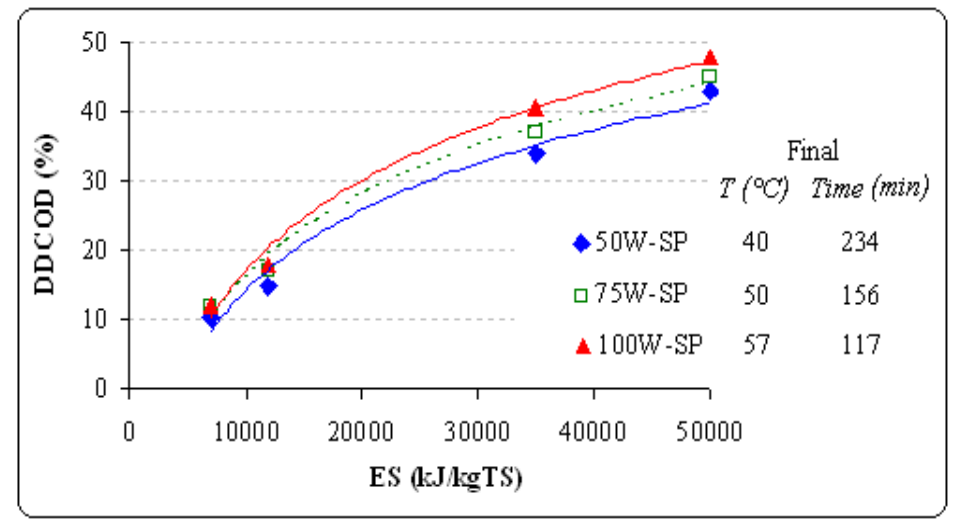

A

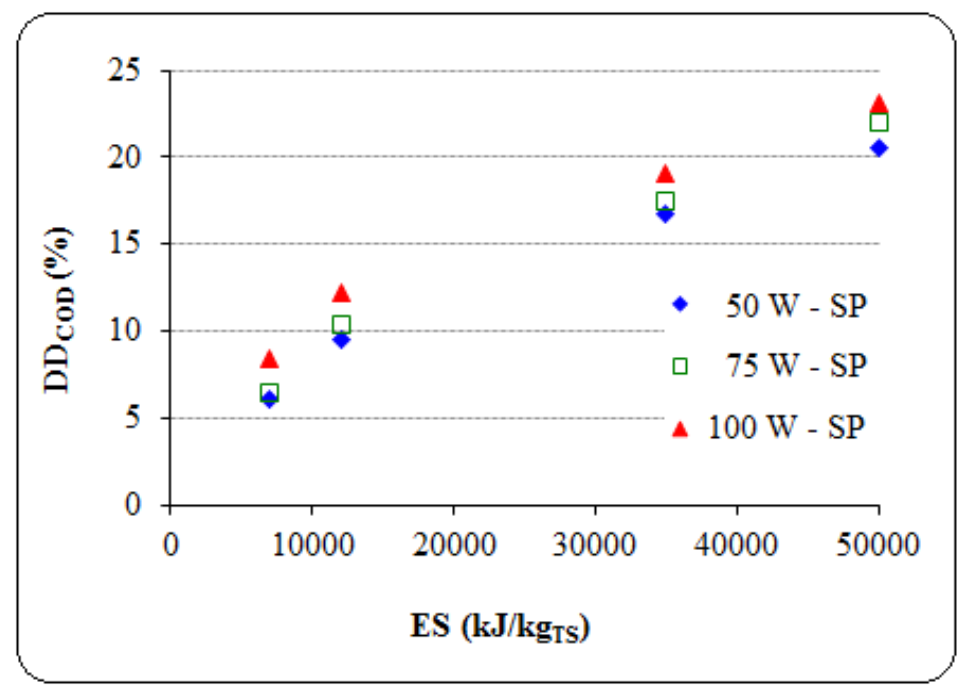

$\mathrm{B}$

Fig 3. Effect of ES and $\mathrm{P}_{\mathrm{US}}$ on DDCOD (SP, $\mathrm{F}_{\mathrm{S}}=20 \mathrm{kHz}$, secondary sludge $\mathrm{TS}=28 \mathrm{~g} / \mathrm{L}-$ Table $1 \mathrm{~B}$, atmospheric pressure): (A) adiabatic US and (B) isothermal US $\left(28^{\circ} \mathrm{C}\right)$. Final temperatures of adiabatic US are also given.

Fig. 3, corresponding to $S P$, shows the positive effect of $P_{U S}$ in the adiabatic mode to be not better than in the isothermal mode, e.g. at $E S$ of $50000 \mathrm{~kJ} / \mathrm{kg}_{\mathrm{TS}}, D D_{C O D}$ increased by $12 \%$ and $13 \%$ from 50 to $100 \mathrm{~W}$ for adiabatic (Fig. 3A) and isothermal US (Fig. 3B), respectively. That meant there was no positive effect of the slight $T$ gain at $100 \mathrm{~W}$ as compared to $50 \mathrm{~W}$ (up to $17^{\circ} \mathrm{C}$ ) despite the $T$ level reached was still moderate.

Conversely, the $50 \mathrm{~W}-U S$ could have benefit from the $T$ increase when switching from $S P$ to $B P$, as in the latter case higher $D D_{C O D}$ were reached despite lower $I_{U S}$ (Fig. 4). With $B P$, the high power was only efficient in adiabatic conditions for $E S$ lower than $20000 \mathrm{~kJ} / \mathrm{kg}_{\mathrm{TS}}$ (when the increase in sludge $T$ and $U S$ duration were still small). The apparently surprising reverse trend at higher $E S$, then higher $T$, might be explained by the result of lower US efficiency at higher $T$. So in this range, the beneficial effect of $T$ through thermal hydrolysis should be overpassed by the detrimental effect on the cavitation efficiency. 


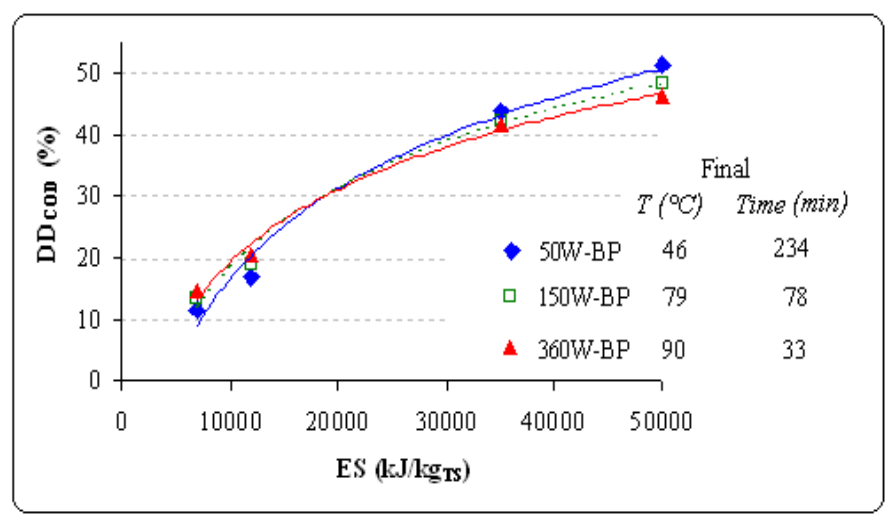

Fig 4. Effect of ES and Pus on DDCoD under adiabatic sonication (BP, $F_{S}=20 \mathrm{kHz}$, secondary sludge TS $=28 \mathrm{~g} / \mathrm{L}-$ Table 1B, atmospheric pressure). Final temperatures of adiabatic US are also given.

To further understand the effect of $T$ on the cavitation efficiency, additional experiments were conducted on another secondary sludge (Table 1C) at $150 \mathrm{~W}$, atmospheric pressure, and isothermal conditions at constant $T$ of 28, 55, 80 ${ }^{\circ} \mathrm{C}$. Results, given in Fig. 5, showed an increase in $D D_{C O D}$ when increasing $T$ from 28 to $55^{\circ} \mathrm{C}$ but a decrease at $T$ of $80{ }^{\circ} \mathrm{C}$. Moreover, there was only small differences in $D D_{C O D}$ between the isothermal $U S$ and the sole thermal hydrolysis at the same $T$ of $80^{\circ} \mathrm{C}$. It then clear that cavitation intensity significantly dampened at a too high $T$ sonication and had much less effect than the thermal hydrolysis.

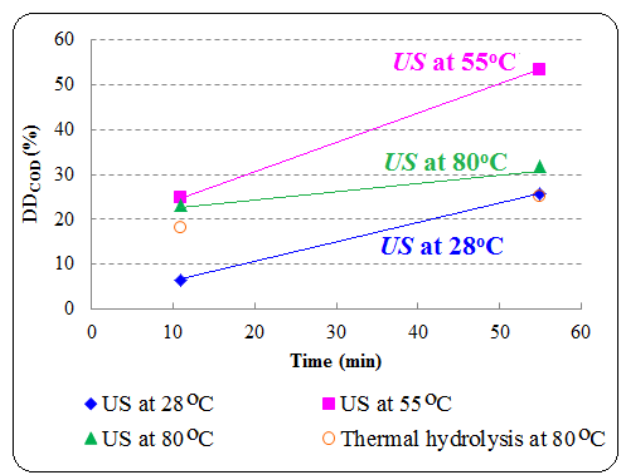

Fig. 5. Effect of temperature on DDCoD by isothermal US $(20 \mathrm{kHz}$, Pus $=150 \mathrm{~W}, \mathrm{BP}$, secondary sludge solutions with $\mathrm{TS}=28 \mathrm{~g} / \mathrm{L}-$ Table $1 \mathrm{c}$, and atmospheric pressure) and thermal hydrolysis.
It should be mentioned that previous results presented in Fig. 4 were achieved on samples rapidly cooled at the end of US. In this case, the beneficial effect of high $T$ for hydrolysis could not be fully recovered during the shortest treatments as the thermal hydrolysis is a slower process than the US solubilisation. Another comparison (using $B P$ ) could then be made based on both the same $E S$ and treatment time, including $U S$ plus maturation under stirring only. At $50 \mathrm{~W}$, adiabatic $U S$ was applied in the $E S$ range of $7000-50000 \mathrm{~kJ} / \mathrm{kg}_{\mathrm{TS}}$ and the solutions were then cooled down immediately to $28^{\circ} \mathrm{C}$. At $150 \mathrm{~W}$ and $360 \mathrm{~W}, U S$ was turned off after the same $E S$ values were reached, but the stirrer was still working (no cooling) until the whole durations equaled those of $50 \mathrm{~W}$ experiments. Temperature evolutions corresponding to experiments at $50000 \mathrm{~kJ} / \mathrm{kg}_{\mathrm{TS}}$ are depicted in Fig. 6. Results of $D D_{C O D}$, given in Fig. 7, showed that at an atmospheric pressure, the sludge disintegration still benefited from the high $P_{U S}$ if enough time was let for the thermal hydrolysis induced by $U S$ heating to operate. Besides, the positive effect of high $P_{U S}-$ short time US at the atmospheric pressure was found, thanks to the thermal hydrolysis after the US disintegration. Of course thermal insulation of our equipment

\section{Trang 28}


would provide even better results by keeping higher $T$, then saved the $U S$ energy for the same result in terms of $D D_{C O D}$.

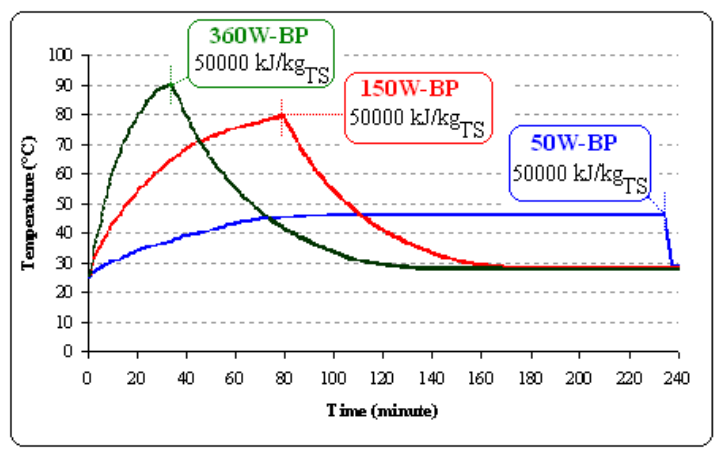

Fig 6. Temperature evolutions for experiments with BP using "adiabatic" US at ES $=50000 \mathrm{~kJ} / \mathrm{kg}_{\mathrm{TS}}$ and stirring afterwards up to $240 \mathrm{~min}: \mathrm{Fs}=20 \mathrm{kHz}$, secondary sludge solutions with TS $=28 \mathrm{~g} / \mathrm{L}$ (Table 1B), atmospheric pressure.

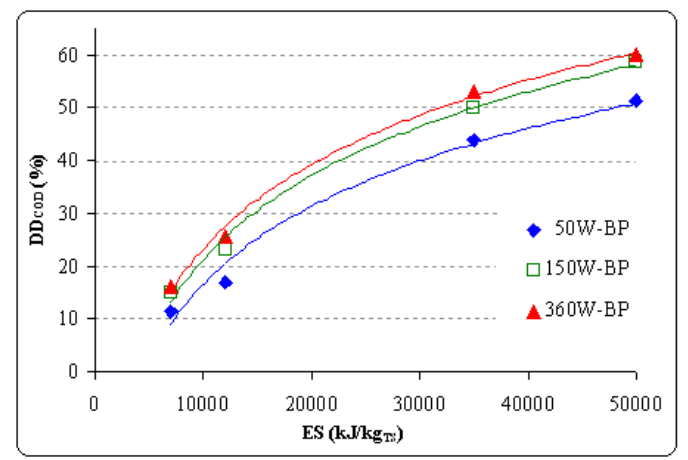

Fig 7. Effect of ES and PUS on DDCOD under adiabatic US followed by stirring up to $240 \mathrm{~min}$ (same conditions as in Fig. 6).

To sum up, effects of $T$ induced by sonication were investigated in details and the important results are as follows: (i) cavitation and thermal hydrolysis seem to show almost additional effects during adiabatic $U S$; (ii) high $P_{U S}$ results in a more rapid increase of $T$; (iii) cavitation acts mainly during the early stage of the adiabatic US, then US being progressively damped by the increasing $T$, thermal hydrolysis takes over, being "boosted" by the initial work of $U S$; (iv) sludge disintegration still benefits from high $P_{U S}$ then high $T$ if enough time is let for the thermal hydrolysis induced by the US heating to operate

It was also noted that $U S$ at high $P_{U S}$ resulted in too high sludge $T$, more than $80{ }^{\circ} \mathrm{C}$ (Fig. 4), out of the safety range recommended by the manufacturer, which might harm the transducer, lead to unstable $P_{U S}$ during $U S$, and are not convenient to provide intense cavitation. In agreement with Kidak et al. [6], it could be suggested for any scale up operation, the $U S$ system should be controlled at the possible highest $T$ in order to both take advantage of $U S$ (cavitation and $T$ effects) and to maintain the system. Sequential US therefore should be investigated to limit the $T$ increase and possibly improve the process.

\section{CONCLUSION}

Effects of $T$ were investigated in conditions of isothermal, adiabatic $U S$ (same $P_{U S}$ ), and sole thermal hydrolysis. Subsequently, its effects were looked into associated with $P_{U S}$ (varying $P_{U S}$ and probe size) for the same $E S$ and then the same treatment duration.

Cavitation and thermal hydrolysis seem to show almost additional effects during adiabatic US. Besides, the thermal hydrolysis of early disrupted sludge by $U S$ is faster than that of the raw sludge. Increasing $P_{U S}$ leads to an increase in the sludge $T$, thereby affecting the cavitation intensity, and then sludge disintegration efficiency. For the $S P$, increasing $P_{U S}$ resulted in a slight $T$ increase, and then the positive effect to sludge disintegration was still observed. For the $B P$, a significant increase in temperature following an increase in $P_{U S}$ caused significant decrease in the cavitation intensity, and then low sludge disintegration efficiency. In cases of the same ES and treatment time, the sludge disintegration still benefits from high $P_{U S}$ if enough time is let for thermal hydrolysis to operate. The combined effect is thus proved: 
cavitation acts mainly during the early stage of the adiabatic $U S$, then $U S$ being progressively damped by the increasing $T$, thermal hydrolysis takes over, being "boosted" by the initial work of $U S$.

It was also noted that $U S$ at high $P_{U S}$ resulted in too high sludge $T$ which might harm the transducer and is not convenient to provide the intense cavitation. Sequential US thus should be investigated to limit the $T$ increase and possibly improve the process.
Acknowledgement: The author acknowledge the financial support from the Vietnam Ministry of Education and Training and Institut National Polytechnique of Toulouse (France). He also thanks Alexandrine BARTHE (Ginestous), Berthe RATSIMBA, Ignace COGHE, Jean-Louis LABAT, Jean-Louis NADALIN, Lahcen FARHI (LGC), Christine REY-ROUCH, Marie-Line PERN, Sylvie SCHETRITE (SAP, LGC), Xavier LEFEBVRE, Anil SHEWANI, Beatriz MORENTE, Delphine DELAGNES (INSA), and SinapTec company for technical and analytical supports.

\section{Ảnh hưởng của nhiệt độ đối với hiệu quả tiền xử lý bùn thải bằng công nghệ siêu âm}

\section{- Lê Ngọc Tuấn}

Trường Đại học Khoa học Tự nhiên, ĐHQG-HCM

\section{TÓM TÁ́T}

Ảnh hưởng của nhiệt độ trong điều kiện siêu âm đẳng nhiệt, siêu âm đoạn nhiệt (cùng công suất - PUS), thủy phân nhiệt (thermal hydrolysis), tác động kết hợp với PUS (thay đổi giá trị PUS và kích thước đầu dò siêu âm) ở cùng giá trị năng lượng siêu âm (ES) và thời gian xử lý được nghiên cứu, đánh giá. Kết quả cho thấy nhiệt độ bùn thải biến đổi phụ thuộc vào giá trị PUS. Ở cùng giá trị ES (các tổ hợp PUS và thời gian siêu âm khác nhau), đối với đầu dò kích thước nhỏ, giá trị PUS cao vẫn mang lại hiệu quả phân rã bùn thải. Tuy nhiên, đối với đầu dò kích thước lớn, hiệu quả phân rã bùn thải tăng nhiệt độ dẫn đến việc ức chế đáng kể cường độ cavitation. Trường hợp cùng $E S$ và thời gian xử lý, bùn thải vẫn phân rã tích cực ở PUS cao nếu thời gian lưu bùn trong lò phản ứng đủ lâu cho quá trình thủy phân nhiệt. Do vậy, ảnh hưởng tổng hợp của cavitation và nhiệt độ nên được xem xét khi tối ưu hóa quy trình siêu âm: cavitation hoạt động chủ yếu trong giai đoạn đầu của quá trình siêu âm đoạn nhiệt, bị ức chế dần dần khi nhiệt độ tăng cao, lúc này thủy phân nhiệt đảm nhận vai trò phân rã bùn thải (và được tăng cường hơn nhờ tác động ban đầu của siêu âm). tương đối thấp ở những PUS cao do sự gia Từ khóa: siêu âm đoạn nhiệt, phân rã bùn thải, ảnh hưởng của nhiệt độ, bùn thải hoạt tính, tiền xử lý bằng siêu âm.

\section{Trang 30}




\section{REFERENCES}

[1]. S. Pilli, P. Bhunia, S. Yan, R.J. LeBlanc, R.D. Tyagi, R.Y. Surampalli, Ultrasonic pretreatment of sludge: A review, Ultrasonics Sonochemistry, 18, 1-18 (2011).

[2]. J.P. Lorimer, T.J. Mason, Sonochemistry: Part 1 - The physical aspects, Chem. Soc. Rev., 16 239-274 (1987).

[3]. C.P. Chu, B.V. Chang, G.S. Liao, D.S. Jean, D.J. Lee, Observations on changes in ultrasonically treated waste-activated sludge, Water Res., 35, 1038-1046 (2001).

[4]. A. Gronroos, H. Kyllonen, K. Korpijarvi, P. Pirkonen, T. Paavola, J. Jokela, J. Rintala, Ultrasound assisted method to increase soluble chemical oxygen demand (SCOD) of sewage sludge for digestion, Ultrason. Sonochem., 12, 115-120 (2005).

[5]. H. Li, Y. Jin, R.B. Mahar, Z. Wang, Y. Nie, Effects of ultrasonic disintegration on sludge microbial activity and dewaterability, $J$. Hazard. Mater, 161, 1421-1426 (2009).

[6]. R. Kidak, A.M. Wilhelm, H. Delmas, Effect of process parameters on the energy requirement in ultrasonical treatment of waste sludge, Chemical Engineering and Processing, 48, 1346-1352 (2009).

[7]. N.T. Le, C. Julcour-Lebigue, H. Delmas, Ultrasonic sludge pretreatment under pressure, Ultrason. Sonochem., 20, 12031210 (2013).

[8]. U. Schmitz, C.R. Berger, H. Orth, Protein analysis as a simple method for the quantitative assessment of sewage sludge disintegration, Water Res., 34, 3682-3685 (2000).

[9]. C. Liu, B. Xiao, A. Dauta, G. Peng, S. Liu, Z. Hu, Effect of low power ultrasonic radiation on anaerobic biodegradability of sewage sludge, Bioresource Technology, 100, 6217-6222 (2009).

[10].T.C. Chang, S.J. You, R.A. Damodar, Y.Y. Chen, Ultrasound pretreatment step for performance enhancement in an aerobic sludge digestion process, Journal of the Taiwan Institute of Chemical Engineers, 42, 801-808 (2011). 